\title{
Responsibility Attitudes Assessment Instrument for Integrated Thematic Learning of Grade III
}

\author{
Elvira Hoesein Radia ${ }^{*}$, Aulia Ika Wulandari ${ }^{2}$ \\ 1,2 Fakultas Keguruan dan Ilmu Pendidikan, Universitas Kristen Satya Wacana, Salatiga, Indonesia
}

\section{A R T I CLE INFO}

Article history:

Received April 09, 2021

Revised April 15, 2021

Accepted October 24, 2021

Available online November 25, 2021

Kata Kunci :

Instrumen Penilaian, Sikap,

Tanggung Jawab, Tematik

Keywords:

Assessment Instrument, Attitude, Responsibility, Thematic

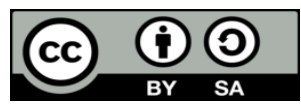

This is an open access article under the CC BY-SA license.

Copyright (ㄷ) 2021 by Author. Published by Universitas Pendidikan Ganesha

\begin{abstract}
A B S T R A K
Kurangnya instrumen penilaian sikap dan tanggung jawab pada pembelajaran tematik terpadu kelas III sekolah dasar. Guru hanya melakukan pengamatan terhadap sikap siswa sehingga tidak memiliki gambaran yang utuh dan valid. Berdasarkan temuan tersebut maka penelitian tujuan penelitian ini yaitu untuk menghasilkan produk instrumen penilaian sikap tanggung jawab pembelajaran tematik terpadu tema 4 subtema 1 pembelajaran 5 kelas III sekolah dasar. Jenis penelitian ini adalah penelitian pengembangan yang merujuk pada teori Borg and Gall dengan menerapkan model pengembangan ADDIE. Populasi penelitian ini adalah siswa kelas III. Sampel ditentukan menggunakan teknik random sampling dengan sampel sebanyak 23 siswa. Teknik pengumpulan data yang digunakan adalah instrumen berupa angket menggunakan skala Likert. Hasil penelitian menunjukkan bahwa instrumen sikap sosial dari 30 (tiga puluh) item pernyataan diperoleh data; reliabilitas instrumen penilaian sikap tanggung jawab pembelajaran tematik terpadu tema 4 subtema 1 pembelajaran 5 kelas III sekolah dasar menunjukkan $\alpha=0.759$ kemudian instrumen masuk kategori reliabel; tingkat validitas instrumen menunjukkan rhitung terendah adalah 0.411 , memiliki nilai Pearson Correlation XTot $\geq 0,3961$ sehingga instrumen dikategorikan valid dan layak digunakan. Dengan menggunakan instrumen penilaian ini, guru dapat menggambarkan dan mengukur sikap tanggung jawab siswa. Selain itu, para guru juga didorong untuk secara konsisten melakukan penilaian standar terhadap sikap tanggung jawab siswa dalam proses pembelajaran dan dengan menemukan gambaran nyata dari sikap siswa guru akan dapat memberikan umpan balik kepada siswanya.
\end{abstract}

\section{A B S T R A C T}

Lack of assessment instruments and responsibilities in integrated thematic learning for grade III elementary schools. The teacher only observes students' attitudes so that they do not have a complete and valid picture. Based on these findings, the research objective of this study was to produce an assessment of the attitude of responsibility for integrated thematic learning theme 4 sub-theme 1 learning 5 grade III elementary school. This type of research is development research that refers to the theory of Borg and Gall by applying the ADDIE development model. The population of this research is third-grade students. The sample was determined using a random sampling technique with a selection of 23 students. The data collection technique used is an instrument in the form of a questionnaire using a Likert scale. The results showed that the social attitude instrument obtained data from 30 (thirty) statement items. The reliability of the integrated thematic learning responsibility assessment instrument theme 4 sub-theme 1 learning 5 grade III elementary school shows $\alpha=0.759$ then the instrument is in the reliable category. The instrument's validity level shows the lowest rcount is 0.411 , has a Pearson Correlation XTot $\geq 0,3961$ so that the instrument is categorized as valid and feasible to use. By using this assessment instrument, teachers can describe and measure students' attitudes of responsibility. In addition, teachers also assess to consistently assess the standard of student attitudes in the learning process and finding an accurate picture of student attitudes will provide feedback to students.

\section{INTRODUCTION}

Curriculum transformation in the education field is considered a way to enhance education policy (Friantary \& Martina, 2018; Lestari, 2018; Subagia \& Wiratma, 2016). However, curriculum development cannot be administered in every school across the country in a short time as it requires gradual implementation and a timeline. Problems may also appear in the curriculum implementation process though the curriculum has been enforced in the 2013 Curriculum implementation process (Febriyanti, 2013; Prasojo et al., 2017; Zulkifli, 2018). Compared with the previous curriculum, the 2013 Curriculum contains several significant changes, including substance, learning process, teachers' roles, lesson plan, and assessment. The implementation of the 2013 Curriculum is an essential step to enhance and develop Indonesia's education quality. However, The Ministry of Education and Culture has pointed out some 
troubles revolving around the new curriculum implementation, including the assessment systems. The 2013 Curriculum assessment methods were way too complex and consuming more time that redirected the teachers' attention from focusing on the students' learning well-being to the administrative process (Astuti \& Darsinah, 2018; Mulyadin, 2016; Wahyudin, 2018). Students' self competencies and quality development throughout the learning process is measured with standards-based assessment administered at elementary schools (Y. I. Siddiq et al., 2020; Subagia \& Wiratma, 2016; Wildan, 2017). The assessment should be based on teachers' objective assessment and limit teachers' subjective perspectives (Darmansyah, 2014; Dessiane \& Kristin, 2021; Oktarina \& Fatonah, 2021). The learning assessment shall be conducted with standardized and objective measurement tools. Assessment is an instrument option that measures the students' progress and achievements in the learning process according to the learning objectives. Contradictically, in learning process in National Elementary School of Karanganyar 2 Karangrayung it was found that assessment instrument for assessing responsibility attitudes of integrated thematic learning theme 4 sub-theme 15 th learning for grade III elementary school hasn't been provided. The fact is this instrument should be utilized to portray the students' development, measure students' learning achievements, and enhance standardsbased learning and teaching.

That condition is contrast with the fact that the assessment in the 2013 Curriculum promotes the application of authentic assessment. It refers to the assessment process that evaluates the students' performance in behavior, knowledge application, and skills achievement in observable tasks that are real and contextual (Friantary \& Martina, 2018; Subagia \& Wiratma, 2016; Wildan, 2017). As one of the essential learning stages, the assessment process takes roles in giving feedback and providing information about the quality of the acquisition on the subject of education (Utami \& Wardani, 2020; Wiana et al., 2017). The attitude aspect is divided into two different categories, namely social attitude and spiritual attitude. The social attitude describes behavior that upholds honesty, discipline, responsibility, politeness, selfconfidence, and tolerance (Latipah et al., 2020; Mahmoudi et al., 2012). As a fact that was found in National Elementary School of Karanganyar 2 Karangrayung Attitude assessment hasn't been provided for the teacher. The instrument should consists of dynamic and complicated activities as it involves values and principles that are often immeasurable (Kusaeri, 2019). In the assessment process in the National Elementary School Karanganyar 2, social attitudes reflected through behaviors and actions performed in interaction with the social environment are still troublesome to be assessed. The field findings reveal that social attitude, specifically responsible attitude, is challenging to observe that is why a valid and reliable instrument must be implemented in the assessment process. By constructing a valid and reliable instrument this research will meet the needs of schools not only in National Elementary School of Karanganyar 2 Karangrayung but also schools in common.

Similar problems are also identified in several elementary schools. Observation and interviews were conducted at the National Elementary School of Karanganyar 2, National Elementary School of Telawah 2, and National Elementary School of Telawah 1 located in Karangrayung, Grobogan Regency. The observation administered at the National Elementary School of Karanganyar 2 revealed that the teachers had implemented attitude assessment throughout the learning process using assessment rubrics available in the teacher textbooks. Thorough and detailed students' attitude assessment had not been conducted as it was only administered a few times by the end of the semester. It was revealed that the teachers had not developed or arranged any attitude assessment instrument yet due to shortcomings in teachers' comprehension in making standardized attitude assessment instruments. An adequate assessment instrument should be able to measure a subject with an accurate measurement with tested validity and reliability (Sugiyono, 2015). Subsequently, the observation and interview at the National Elementary School of Telawah 2 revealed that the teachers implemented attitude assessment using adapted rubrics or referring to the provided rubrics in the teacher textbooks. However, the teachers did not arrange learning matrixes before creating the assessment instrument. Therefore, detailed assessment indicators were not available for the attitude assessment.

The teachers also did not test the instruments' validity and reliability. Oftentimes, the teachers assessed students' attitudes through observation without using instruments, which only included several aspects. Meanwhile, instruments take an essential role in conducting an optimized assessment process as indicators that cover the assessed aspects. The observation at National Elementary School of Telawah 1 found that the teachers only conducted students' attitude assessment once throughout the semester using the rubric provided in the teacher textbooks. The assessment specified only on knowledge and the attitude assessment was only conducted through observation, which reduced the authenticity. Authentic assessment refers to a thorough assessment that scopes three aspects, including knowledge, attitude, and skills. Through the observation and interview sessions, similar problems were recognized from the schools. The problems were teachers' little to no experience in creating attitude assessment instruments as well as 
testing the validity and reliability of the assessment instruments. Responsible attitude assessment instruments were also unavailable in the observed schools.

Moreover, assessment instruments or evaluation tools are frameworks used to ensure tasks' effectiveness and efficiency in performance and goal achievements (Praslova, 2010; Zulfiani et al., 2020). Assessment can be used to diagnose the strengths and weaknesses of the students, to monitor their progress, to determine their ranking, and to determine the effectiveness of instructions given by the teacher (F. Siddiq et al., 2019; Wartawan, 2018). Instruments are also used to measure indicators or competencies achieved by grading according to particular categories explicitly and precisely, so the measurement results' stability is relatively similar in identical contexts (Nurtanto et al., 2020; Suratmi et al., 2020; Wei et al., 2021). The essential characteristics that should be included in an assessment instrument are validity and reliability. An adequate instrument is able to generate results that are coherent with the measured objects. An instrument is considered valid if the tool can measure the target according to the assessment objectives. The assessment of responsible attitude scopes students' attitudes towards learning materials, teachers/educators, the learning process, and values or norms related to the learning materials ((Safitri \& Harjono, 2021; Ulfa, 2019). An adequate assessment process should be oriented to two main priorities, namely the main purpose of education (e.g., learning from students' experience to create meaningful learning process) and learners' diversity accommodation, including their learning styles to enhance the upcoming learning design and planning (Wiana et al., 2017). Attitude assessments, specifically the responsible attitude, are rarely implemented optimally due to various factors, such as teachers' skills, technology resources, and information resources. The most significant problem encountered by the teachers is a lack of comprehension in arranging assessment instruments and conducting attitude assessment (Kartowagiran \& Jaedun, 2016; Leutner et al., 2017).

Students' environment and social circle may affect their development and formation of social and spiritual attitudes. If a child engages in a respectable environment, positive behaviors can grow and develop along the way, while an unhealthy environment sets the child to internalize negative behaviors ((Dasopang \& Montessori, 2018; Maison et al., 2021; Öztürk et al., 2020). A study on students' attitudes as well as students' attitude assessment instruments can provide accurate follow-up to overcome the problems. The unavailability of valid and reliable attitude assessment instruments based on the field observation and interview results encouraged the researchers to create and develop assessment instruments that specifically accommodate social attitude core competency. In the 2013 Curriculum, students' social attitude core competency assessment consists of honesty, discipline, self-confidence, politeness, thoughtfulness, hard-working, independence, and responsibility (Darmansyah, 2014; Kuntoro \& Wardani, 2020). The attitude core competencies should be integrated into the learning process as equally as knowledge and skills through attitude habituation, positive attitude customization, and character education enforcement at the primary level.

Similarly, previous research found that the implementation of the attitude assessment process. It was discovered that the assessment was administered through assignments and observation in the classroom learning process (Hindati, 2018). Therefore, students' performance throughout the learning activities can be assessed objectively, authentically, and process-oriented to avoid assessing students with final results only (Sugihartini \& Agustini, 2017). Other research found that discovered some schools only conducted knowledge aspect assessment (Kuntoro, 2020). According to the problems recognized from the past research, the present research aims to develop students' social attitude measurement instruments, create procedure to develop social attitude assessment instrument using Likert scale, and test the validity and reliability of the instrument products. The developed instrument is expected to facilitate affective assessment implementation, precisely responsible social attitude, so the students' attitude description will follow the competencies listed in the curriculum. Therefore, the research aims to determine students' responsible attitude measurement and generate students' responsible attitude measurement instruments with tested validity and reliability.

\section{METHODS}

The research was carried out through Research and Development (R\&D) design. R\&D refers to a research methodology that focuses on investigation, design, production, and validity tests for the researched products (Sugiyono, 2014). The R\&D research aimed to develop a product in which assessment instruments for responsible attitude in the form of Likert scale. The Likert scale formulation of the research was built upon behavioural Likert scale model principles to measure students' attitude ( Mawardi, 2019). The definition and indicator arrangement in this research referred to the Primary Level Assessment Guidelines, which would be further developed to form assessment instrument products. To carry out the developmental research, Borg and Gall's R\&D procedure was selected as the research design. Borg and Gall's 
developmental research model follows the following procedures, namely: 1) Early data collection and research, 2) Planning, 3) Preliminary product draft design, 4) Preliminary field test, 5) Preliminary product revision, 6) Operational field test, 7) Operational product revision, 8) Field implementation test, 9) Final product revision, and 10) Dissemination and implementation. For the research, the conducted steps were only up to the preliminary field test stage. The developmental research procedure may work more effectively if it is integrated with the development model. The Borg and Gall model was integrated with more development models, such as the ADDIE model. The ADDIE model is an analytical approach that emphasizes how each active component interacts with one another according to sequential phase coordination (Rayanto \& Sugianti, 2020). The phases of the ADDIE model are analysis, design, development, implementation, and evaluation. The evaluation results in each phase in interactive, so the following phase can be developed based on the results. Thus, the ADDIE model is a basic model that can be used to develop any product (Krismony et al., 2020).

The research was conducted in the National Elementary School of Karanganyar 2, Karangrayung, Grobogan Regency. The measurement instrument used for the social attitude assessment of the students was a responsible attitude questionnaire with a Likert scale. The instrument arrangement was begun with a literature study to seek supporting theories for the research and the concept of responsibility as the Likert scale instrument's object. The following step was determining the operational definition of "responsibility" through formulating the attitude indicators by integrating the three attitude aspects, namely cognition, affection, and conation, to form questions. After the indicators arrangement, the matrix of attitude instrument was developed with Likert scale. The instrument matrix was transformed into 30 statements, which underwent a face validity test before administered to samples. The face validity test involved two lecturers in examining the designed instruments. One lecturer was an expert in evaluation, while the other was a language expert. The face validity test instrument employed the Likert scale with 1 to 5 degrees, in which criteria 1 (poor), 2 (fair), 3 (neutral), 4 (good), and 5 (excellent). The collected data from expert judgement proceeded to be analyzed using percentage and categorical descriptive analysis technique to determine the product's decency before implementation. The scores generated from close-ended questionnaires were presented in the form of percentage. The score of the measurement results using a closed questionnaire will be presented by adding up the actual score (the score given by the expert validator) then divided by the ideal score (maximum score of all items) then multiplied by $100 \%$. The percentage calculation results are then categorized into the Very High category for the interval $81 \%-100 \%$, the High category for the $61 \%-80 \%$ interval, the Enough category for the $41 \%-60 \%$ interval, the Low category for the interval $21 \%-40 \%$, the Very category Low for the interval $0 \%-20 \%$.

The grade III responsible attitude assessment instrument validity test could be considered adequate for tests administered to respondents if it reached at least the high category or $\geq 61 \%$ (Mawardi, 2014). The face validity test results were revised according to the experts' suggestions, then distributed to respondents in National Elementary School of Karanganyar 2. The research was carried out up to the preliminary field test stage. The phase focused on implementing the product to 23 students of the National Elementary School of Karanganyar 2 through descriptive data analysis technique, in which categorization, percentage, and validity and reliability test. The instrument validity and reliability were proceeded using IBM SPSS 24 program for Windows.

\section{RESULT AND DISCUSSION}

\section{Results}

The preliminary research covered students' social attitude learning outcome at the National Elementary School of Karanganyar 2, Karangrayung, Grobogan Regency. The first significant problem was discovered in the research field through interviews with and observation of grade III teachers of the National Elementary School of Karanganyar 2 regarding the instrument unavailability. It was revealed that measurement tools specifically for responsibility social attitude with proven validity and reliability were not provided. Attitude assessment in the research field only relied on teachers' observations, which could not precisely depict and measure students' repertoire about attitude. Teachers also encountered more troubles, such as insufficient comprehension and time to develop standardized instruments. Therefore, the researchers arranged assessment instruments for responsible attitude using the Likert scale for grade III of elementary school. After preliminary research and literature review, the researchers proceeded to the planning phase. The planning stage involved learning syllabus review, basic competency selection, learning design, and lesson plan arrangement for integrated thematic learning according to basic competencies and selected learning topics. The attitude indicators were developed based on Likert scale model principles. The attitude indicators were arranged in the assessment instrument matrix, which developed into an instrument consisting of 30 statements integrated with the lesson plan. The arranged matrix will be the 
point of reference in composing 30 statements which contain the instrument of attitudes, covering the aspects of cognitive, affective, and conative. The development of attitude instrument products implementing the Likert scale only focuses on the object of responsibility attitude. The assessment matrix instrument is presented in table 1.

Table 1. Matrix of Responsibility Attitudes Instrument by Implementing Likert Scale in Thematic Learning of Grade III Theme 4 My Rights and Obligations Sub-theme 1 My Rights and Obligations at Home Lesson 5

\begin{tabular}{|c|c|c|c|c|c|c|c|c|}
\hline $\begin{array}{l}\mathbf{N} \\
\mathbf{o}\end{array}$ & $\begin{array}{c}\text { Core } \\
\text { Competen } \\
\text { ce }\end{array}$ & $\begin{array}{c}\text { Basic } \\
\text { Competen } \\
\text { ce }\end{array}$ & Indicator & $\begin{array}{c}\text { Indicator } \\
\text { Component } \\
s\end{array}$ & $\begin{array}{l}\text { Attitude } \\
\text { Aspects }\end{array}$ & $\begin{array}{l}\text { Observed } \\
\text { Aspects }\end{array}$ & $\begin{array}{c}\text { Instru } \\
\text { ment } \\
\text { Style }\end{array}$ & $\begin{array}{l}\text { Total } \\
\text { Items }\end{array}$ \\
\hline 1. & $\begin{array}{l}\text { 2. Showing } \\
\text { attitudes of } \\
\text { being } \\
\text { honest, } \\
\text { disciplined, }\end{array}$ & $\begin{array}{c}2.2 \\
\text { Fulfilling } \\
\text { the rights } \\
\text { and } \\
\text { obligations }\end{array}$ & $\begin{array}{l}2.2 .1 \\
\text { Responsib } \\
\text { ly fulfilling } \\
\text { the rights } \\
\text { and }\end{array}$ & $\begin{array}{l}\text { The nature } \\
\text { of } \\
\text { responsibili } \\
\text { ty }\end{array}$ & Cognitive & $\begin{array}{l}\text { The nature of } \\
\text { responsibility }\end{array}$ & $\begin{array}{l}\text { Likert } \\
\text { Scale }\end{array}$ & 2 \\
\hline 2. & $\begin{array}{l}\text { responsible } \\
\text {, polite, } \\
\text { solicitude, } \\
\text { and } \\
\text { confident }\end{array}$ & $\begin{array}{l}\text { as a } \\
\text { member of } \\
\text { the family } \\
\text { and school. }\end{array}$ & $\begin{array}{l}\text { obligation } \\
\text { s as a } \\
\text { member of } \\
\text { the family } \\
\text { and }\end{array}$ & Studying & Conative & $\begin{array}{c}\text { Studying } \\
\text { consistently as } \\
\text { the } \\
\text { responsibility } \\
\text { of a student }\end{array}$ & & 2 \\
\hline \multirow[t]{4}{*}{3.} & $\begin{array}{c}\text { in } \\
\text { interacting } \\
\text { with family, } \\
\text { friends, }\end{array}$ & & school. & $\begin{array}{l}\text { Completing } \\
\text { tasks }\end{array}$ & Cognitive & $\begin{array}{l}\text { The essence of } \\
\text { completing } \\
\text { tasks }\end{array}$ & & 2 \\
\hline & $\begin{array}{l}\text { teachers, } \\
\text { and } \\
\text { neighbors. }\end{array}$ & & & & Affective & $\begin{array}{l}\text { Agreeing or } \\
\text { disagreeing to } \\
\text { do the given } \\
\text { assignments in } \\
\text { the group } \\
\text { projects }\end{array}$ & & 2 \\
\hline & & & & & & $\begin{array}{c}\text { Doing } \\
\text { homeworks }\end{array}$ & & 2 \\
\hline & & & & & Conative & $\begin{array}{l}\text { Submitting the } \\
\text { assignments in } \\
\text { time }\end{array}$ & & 2 \\
\hline \multirow[t]{2}{*}{4.} & & & & $\begin{array}{l}\text { Obeying the } \\
\text { school } \\
\text { regulation }\end{array}$ & Affective & $\begin{array}{l}\text { Finding the } \\
\text { daily classroom } \\
\text { cleaning } \\
\text { schedule } \\
\text { enjoyable or } \\
\text { not enjoyable }\end{array}$ & & 2 \\
\hline & & & & & Conative & $\begin{array}{l}\text { Wearing } \\
\text { appropriate } \\
\text { clothes } \\
\text { following the } \\
\text { school } \\
\text { regulations. }\end{array}$ & & 2 \\
\hline 5. & & & & $\begin{array}{l}\text { Obeying } \\
\text { and } \\
\text { respecting } \\
\text { the teachers }\end{array}$ & Affective & $\begin{array}{l}\text { Feeling } \\
\text { contented or } \\
\text { not contented } \\
\text { when the }\end{array}$ & & 2 \\
\hline
\end{tabular}




\begin{tabular}{|c|c|c|c|c|c|c|c|c|}
\hline $\begin{array}{l}\mathbf{N} \\
\mathbf{0}\end{array}$ & $\begin{array}{c}\text { Core } \\
\text { Competen } \\
\text { ce }\end{array}$ & $\begin{array}{c}\text { Basic } \\
\text { Competen } \\
\text { ce }\end{array}$ & Indicator & $\begin{array}{c}\text { Indicator } \\
\text { Component } \\
\text { s }\end{array}$ & $\begin{array}{l}\text { Attitude } \\
\text { Aspects }\end{array}$ & $\begin{array}{c}\text { Observed } \\
\text { Aspects }\end{array}$ & $\begin{array}{l}\text { Instru } \\
\text { ment } \\
\text { Style }\end{array}$ & $\begin{array}{l}\text { Total } \\
\text { Items }\end{array}$ \\
\hline & & & & & & $\begin{array}{l}\text { teachers give } \\
\text { me advices }\end{array}$ & & \\
\hline & & & & & Conative & $\begin{array}{c}\text { Respecting } \\
\text { teachers at } \\
\text { school or when } \\
\text { meeting them } \\
\text { outside the } \\
\text { school }\end{array}$ & & 2 \\
\hline \multirow[t]{3}{*}{6.} & & & & $\begin{array}{l}\text { Admitting } \\
\text { mistakes }\end{array}$ & Cognitive & $\begin{array}{c}\text { The essence of } \\
\text { admitting } \\
\text { mistakes }\end{array}$ & & 2 \\
\hline & & & & & Affective & $\begin{array}{l}\text { Agreeing or } \\
\text { disagreeing to } \\
\text { accept the risk } \\
\text { of the action } \\
\text { taken }\end{array}$ & & 2 \\
\hline & & & & & Conative & $\begin{array}{l}\text { I should } \\
\text { apologize for } \\
\text { the mistakes I } \\
\text { made. }\end{array}$ & & 2 \\
\hline \multirow[t]{2}{*}{7.} & & & & $\begin{array}{c}\text { Being } \\
\text { disciplined }\end{array}$ & Affective & $\begin{array}{l}\text { Willingly or not } \\
\text { willingly } \\
\text { returning the } \\
\text { borrowed } \\
\text { items }\end{array}$ & & 2 \\
\hline & & & & & Conative & $\begin{array}{l}\text { Always taking } \\
\text { care of the } \\
\text { books lent by } \\
\text { the library }\end{array}$ & & 2 \\
\hline
\end{tabular}

The instrument of responsible attitudes assessment was in the form of a Likert scale questionnaire with a non-test assessment. The indicators were adjusted to the aspects of attitudes that were potentially measured from each indicator and developed into 30 statements consisting of positive (favorable) and negative (unfavorable) statements. The respondents presented their answers of each instrument item in different degrees, specifically from the highly positive to the most negative, which clarified with several terms as follows: strongly agree (SA), agree (A), uncertain (U), disagree (D), and strongly disagree (SD). The data collected from the questionnaire was then analyzed by quantifying with the following scores: positive (favorable) statement scores, including: strongly agree $=5$; agree $=4$; uncertain $=3$; disagree $=2$; strongly disagree $=1$; negative (unfavorable) statement scores, namely: strongly agree $=1$; agree $=2$; uncertain $=3$; disagree $=4$; strongly disagree $=5$. After obtaining the product, the following step was undergoing tests and trials on the products. Product tests and trials were undertaken progressively, namely in 2 stages of limited trials. The initial product statements were evaluated theoretically, exceptionally expert validation tests and empirical tests that involve elementary school students. The expert validation test result obtained a score of $76 \%$, considered in the high category of validity level. Additionally, approximately $80 \%$ were gained by linguists, also categorized as high. Experts who reviewed the product also offered suggestions for the product to be improved before being examined in a further limited field. The assessed aspect was linguistic. The result from both evaluation experts and linguists revealed that most of the statements gained from the attitudes assessment instrument were in accordance with the aspects of attitudes to be assessed. 
Furthermore, the obtained criterion of instrument validity was regarded as a high average validity level and considered worth testing as it earned a score of $>61 \%$.

The theoretically tested products with suggestions offered by experts had been improved according to the experts' advice. In conclusion, the product could be tested. Following that, the responsibility attitudes assessment instrument undertook tests and trials in grade III at SD Negeri 2 Karanganyar, involving 23 students to fill in 30 statements on the questionnaire. The result of these product tests and trials obtained was 0.411 . It was the lowest $r_{\text {count }}$ (correlation) of the 30 statements. In this case, the score of $r_{\text {count }} 0.411$ was in the 0.41-0.60 range and categorized as valid with a sufficient validity level. Next, the product tests and trials also scored 0.829 for the highest $r_{\text {count }}$ (correlation), between the range of $0.81-1.00$. Its level of validity was considered very high. If all the instruments counted as $r_{\text {count }}>r_{\text {table, }}$ the $r_{\text {table }}$ was 0.3961 . It occurred because total $r_{\text {count }}>0.3961$. In conclusion, all the statements were acknowledged as valid. The coefficient validity of the instruments could be identified by using IBM SPSS 24 program for Windows. It could be operated by clicking on Analyze, Correlate, Bivariate, putting a checkmark on Pearson, Two-tailed and flag significant correlations, and clicking $\mathrm{OK}$ at last. As a table entitled Correlations appeared, if it showed the total value as in the Pearson Correlation XTot $\geq 0.3961$, then the result was considered as valid. The overview of validity distribution of the instrument from the validity test is available in Table 2.

Table 2. Instrument Items Validity Percentage Distribution

\begin{tabular}{cccc}
\hline Valid Interpretation & \multicolumn{1}{c}{ Item Number } & Total & Percentage (\%) \\
\hline \multirow{3}{*}{$r \geq 0.360$} & $1,2,3,4,5,6,7,8,9,10,11$, & 30 & 100 \\
& $12,13,14,15,16,17,18,19$, & & \\
& $20,21,22,23,24,25,26,27$, & & \\
& $28,29,30$. & & \\
\hline
\end{tabular}

According to the validity analysis results using SPSS, it can be inferred that all statement items can be considered valid with total $r_{\text {count }}>0.411$. The 1 st phase final product test result was $0.432=r_{\text {count }}=0.743$, so the instrument validity was also high. The 2 nd phase final product test result was $0.375=r_{\text {count }}=0.756$, so the instrument validity was considered high. The instrument consisted of 30 valid items $(100 \%)$. The instrument validity test results through SPSS the 23rd version analysis revealed the average of $r_{\text {count }}>0.30$ in a small classroom test. From 140 statements arranged in the instrument, 18 statements were revealed to be invalid and left 122 items. The second test with big classroom dissimilation involving 140 students generated 15 invalid items and left 105 valid statements in the instrument.

The development and tests of instruments for grade III students' responsible attitude assessment revealed that all items were categorized as valid. Reliability test aims to examine a tool's ability in providing constant and consistent measurement results (Wardani et al., 2012: 344). Each statement item can be considered to have high reliability if the reliability index is close to 1.00 , while low reliability usually produces a reliability index close to 0.00 . Reliability index range is divided into 5 categories, namely 1 ) highly reliable with $0.80-1.00$ index, 2) reliable with $<0.80-0.60$ index, 3) moderate with $<0.60-0.40$ index, 4) poorly reliable with $<0.40-0.20$ index, and 5) unreliable with $<0.20$ index. A reliable instrument should be able to generate the same data results from the same object despite being applied multiple times (Sugiyono, 2014). The reliability of an instrument is also determined by its consistency in producing data after numerous tests. In addition, Kuntoro and Wardani (2020) asserted that an instrument with high reliability could portray more realistic data with precision and consistency in the test scores. According to the experts' beliefs, it can be concluded that the higher the reliability category an instrument has, the better it is due to its higher accuracy. Instrument's reliability coefficient can be identified with IBM SPSS 24 for Windows by clicking Analyze, Scale, Reliability Analysis, checking Item, Scale, Scale if Item Deleted, Continue, and Clicking OK. The Reliability Statistics table will soon appear. If the Cronbach's Alpha value is $>0.361$, the instrument is considered to be reliable. Instrument reliability distribution in restricted field tests produced instrument reliability levels with $\alpha=0.758$ under the reliable for use category. Reliability level with $0.60<\alpha<0.80$ resulting 0.758 was categorized to be highly reliable.

\section{Discussion}

The research and development results of this assessment instruments for grade III students' responsible attitude disclosed strong reliability in measuring students' attitudes. According to the test results conducted by behaviour evaluation and language experts, as well as the product's validity test in the field, it was identified that the responsibility attitude assessment instrument is categorized to be highly valid and feasible. Firstly, the assessment results of the responsible attitude assessment instrument for grade III students revealed that each instrument item was classified as valid. A valid instrument was 
considered suitable for use if it could assess and determine which competencies were achieved by the students (Hidayat et al., 2018; Purnami et al., 2021; Suratmi et al., 2020). Further, the responsible attitude assessment instrument for grade III students was able to measure students' attitude objectively. The design and formulation of the assessment instrument was developed according to the Primary Level Assessment Guidelines as well as referring to the principles of Likert scale model arrangement to assess students' attitude (Glassman et al., 2021; Kalalo, 2013; Syauqi et al., 2020). Secondly, the responsible attitude assessment instrument for grade III students was practical, so teachers could easily apply it. The social attitude assessment application through a Likert scale-based questionnaire specifically assessed students' individual social attitude with a convenient data result analysis process that accurately assessed according to the competencies (Maulida et al., 2020; Mawardi, 2019). Subsequently, the developed instrument had been adjusted to students' daily activity, so it was expected that the students could easily understand the teacher's instruction without repeating the explanation.

The current study provides an implication for further practice that suggests the teachers can use the developed assessment instruments to measure the attitude towards students' responsibility in grade III. The instrument that had been developed was adapted to thematic learning, which was relevant to the students' age development. It also can be used as a guide or measuring tool in the following academic years. Additionally, a reliable instrument of attitude assessment offers a benefit as it was considered as a measuring tool that could provide consistent results because it managed to show constant results in measuring the same event at different times (Hamdi et al., 2018; Hidayat et al., 2018).

\section{CONCLUSION}

In conclusion the result of this research has directly impacted to the teachers not only in National Elementary School of Karanganyar 2 but also all teachers from nasional school who teach grade III. By using this assessment instrument, the teachers can depict and measure the responsible attitude of students. Moreover, the teachers are also encouraged to consistently conduct standardized assessments for students' responsible attitude in the learning process and by finding the real picture of students attitude the teacher will be able to give feedback to their students.

\section{REFERENCES}

Astuti, S. I., \& Darsinah, D. (2018). Penilaian Autentik Berbasis Kurikulum 2013 di SD Negeri Mangkubumen Kidul No. 16 Surakarta. Manajemen Pendidikan, 13(2), 165-174. https://doi.org/10.23917/jmp.v13i2.7484.

Darmansyah, D. (2014). Teknik Penilaian Sikap Spritual dan Sosial dalam Pendidikan Karakter di Sekolah Dasar 08 Surau Gadang Nanggalo. Al-Ta Lim Journal, 21(1), 10-17. https://doi.org/10.15548/jt.v21i1.67.

Dasopang, M. A., \& Montessori, M. (2018). Pengaruh Lingkungan dan Kebiasaan Orangtua Terhadap Perilaku dan Sikap Moral Anak. Journal of Civic Education, 1(2), 98-107. https://doi.org/https://doi.org/10.24036/jce.v1i2.198.

Dessiane, S. T., \& Kristin, F. (2021). Pengembangan Instrumen Penilaian Sikap Sosialpembelajaran Tematik Kelas 4 SD. Jurnal Pendidikan Ilmu Pengetahuan Sosial Indonesia, 6(1), 21-26. https://doi.org/10.26737/jpipsi.v6i1.2310.

Febriyanti. (2013). Article Kurikulum Pendidikan Tinggi Di Era Globalisasi (Pergeseran Dari Kurikulum Inti Dan Institusional Ke Kurikulum Berbasis Kompetensi). Ta'di Jurnal Pendidikan Islam, 18(2). https://doi.org/10.19109/tjie.v18i02.51.

Friantary, H., \& Martina, F. (2018). Evaluasi Implementasi Penilaian Hasil Belajar Berdasarkan Kurikulum 2013 oleh Guru Bahasa Inggris dan Bahasa Indonesia di MTS Ja-Alhaq Kota Bengkulu. Silampari Bisa: Jurnal Penelitian Pendidikan Bahasa Indonesia, Daerah, Dan Asing, 1(2), 76-95. https://doi.org/10.31540/silamparibisa.v1i2.202.

Glassman, M., Kuznetcova, I., Peri, J., \& Kim, Y. (2021). Cohesion, collaboration and the struggle of creating online learning communities: Development and validation of an online collective efficacy scale. Computers and Education Open, 2(January), 100031. https://doi.org/10.1016/j.caeo.2021.100031.

Hamdi, S., Suganda, I. A., \& Hayati, N. (2018). Developing higher-order thinking skill (HOTS) test instrument using Lombok local cultures as contexts for junior secondary school mathematics. Research and Evaluation in Education, 4(2), 126-135. https://doi.org/10.21831/reid.v4i2.22089.

Hidayat, T., Susilaningsih, E., \& Kurniawan, C. (2018). The Effectiveness of Enrichment Test Instruments Design to Measure Students' Creative Thinking Skills and Problem-Solving. Thinking Skills and Creativity, 29, 161-169. https://doi.org/10.1016/j.tsc.2018.02.011. 
Hidayati, W. (2018). Peran Guru Dalam Mengembangkan Sikap Sosial Siswa Pada Pembelajaran Tematik Di Kelas 2B Min 2 Kota Tangerang Selatan. https://doi.org/10.22373/jid.v16i2.593.

Kalalo, R. (2013). Customer Relationship Management Dan Kualitas Pelayanan Pengaruhnya Terhadap Loyalitas Konsumen Pt. Matahari Dept. Store, Manado. Jurnal Riset Ekonomi, Manajemen, Bisnis Dan Akuntansi, 1(4), 1553-1561. https://doi.org/10.35794/emba.v1i4.2960.

Kartowagiran, B., \& Jaedun, A. (2016). Model Asesmen Autentik Untuk Menilai Hasil Belajar Siswa Sekolah Menengah Pertama (Smp): Implementasi Asesmen Autentik Di Smp. Jurnal Penelitian Dan Evaluasi Pendidikan, 20(2), 131. https://doi.org/10.21831/pep.v20i2.10063.

Krismony, N. P. A., Parmiti, D. P., \& Japa, I. G. N. (2020). Pengembangan Instrumen Penilaian Untuk Mengukur Motivasi Belajar Siswa SD. Jurnal Ilmiah Pendidikan Profesi Guru, 3(2), 249. https: //doi.org/10.23887/jippg.v3i2.28264.

Kuntoro, B. T., \& Wardani, N. S. (2020). Pengembangan Instrumen Penilaian Sikap Sosial Pembelajaran Tematik Kelas III SD. Jurnal Ilmiah Wahana Pendidikan, 6(3), 295-307. https://doi.org/10.5281/zenodo.3737983.

Kusaeri, K. (2019). Penilaian Sikap Dalam Pembelajaran Matematika. JPM : Jurnal Pendidikan Matematika, 5(2), 61. https://doi.org/10.33474/jpm.v5i2.1588.

Latipah, E., Kistoro, H. C. A., \& Khairunnisa, I. (2020). Scientific Attitudes in Islamic Education Learning: Relationship and the Role of Self-Efficacy and Social Support. Edukasia: Jurnal Penelitian Pendidikan Islam. https://doi.org/10.21043/edukasia.v15i1.7364.

Lestari, N. D. (2018). Analisis Penerapan Kurikulum 2013 Dalam Meningkatkan Kualitas Pembelajaran Ekonomi Di Sma Negeri Se-Kota Palembang. Jurnal Neraca: Jurnal Pendidikan Dan Ilmu Ekonomi Akuntansi, 2(1), 68-79. https://doi.org/10.31851/neraca.v2i1.2190.

Leutner, D., Fleischer, J., Grunkorn, J., \& Klieme, E. (2017). Competence Assessment in Education Research, Models and Instruments. Springer Nature. https://doi.org/10.1007/978-3-319-50030-0_16.

Mahmoudi, E., Samad, A. bt A., \& Razak, N. Z. B. A. (2012). Attitude and Students' Performance in Computer Assisted English Language Learning (CAELL) for Learning Vocabulary. Procedia - Social and Behavioral Sciences, 66. https://doi.org/10.1016/j.sbspro.2012.11.293.

Maison, M., Kurniawan, D. A., \& Anggraini, L. (2021). Perception, Attitude, and Student Awareness in Working on Online Tasks During the Covid-19 Pandemic. Jurnal Pendidikan Sains Indonesia, 9(1), 108-118. https://doi.org/10.24815/jpsi.v9i1.18039.

Maulida, I., Dibia, I. K., \& Astawan, I. G. (2020). The Development of Social Attitude Assessment Instrument and Social Studies Learning Outcomes Grade IV on Theme of Indahnya Keragaman di Negeriku. Indonesian Journal of Educational Research and Review, 3(1), 12. https://doi.org/10.23887/ijerr.v3i2.25823.

Mawardi, M. (2014). Model Desain Pembelajaran Konsep Dasar PKn Berbasis Belajar Mandiri Menggunakan Moodle. Widya Sari Press.

Mawardi, M. (2019). Rambu-rambu Penyusunan Skala Sikap Model Likert untuk Mengukur Sikap Siswa. Scholaria: Jurnal Pendidikan Dan Kebudayaan, 9(3), 292-304. https://doi.org/10.24246/j.js.2019.v9.i3.p292-304.

Mulyadin. (2016). Implementasi Kebijakan Pembelajaran Tematik Terpadu Kurikulum 2013 Di SDN Kauman 1 Malang Dan Sd Muhammadiyah 1 Malang. Jurnal Pendidikan Edutama, 3(2), 31 - 48. https://doi.org/10.30734/jpe.v3i2.35.

Nurtanto, M., Arifin, Z., Sofyan, H., Warju, W., \& Nurhaji, S. (2020). Development of model for professional competency assessment (Pca) in vocational education: Study of the engine tune-up injection system assessment scheme. Journal of Technical Education and Training, 12(2), 34-45. https://doi.org/10.30880/jtet.2020.12.02.004.

Oktarina, A., \& Fatonah, S. (2021). Pengamatan Tentang Pembelajaran Dan Penilaian Pada Anak Usia Dini Di Era Pandemi Covid-19. Cakrawala Dini: Jurnal Pendidikan Anak Usia Dini, 12(1). https://doi.org/10.17509/cd.v12i1.30278.

Öztürk, M., Akkan, Y., \& Kaplan, A. (2020). Reading comprehension, Mathematics self-efficacy perception, and Mathematics attitude as correlates of students' non-routine Mathematics problem-solving skills in Turkey. International Journal of Mathematical Education in Science and Technology, 51(7), 1042-1058. https://doi.org/10.1080/0020739X.2019.1648893.

Praslova, L. (2010). Adaptation of Kirkpatrick's four level model of training criteria to assessment of learning outcomes and program evaluation in Higher Education. Educational Assessment, Evaluation and Accountability, 22(3), 215-225. https://doi.org/10.1007/s11092-010-9098-7.

Prasojo, L. D., Wibowo, U. B., \& Hastutiningsih, A. D. (2017). Manajemen Kurikulum Program Profesi Guru Untuk Daerah Terdepan, Terluar, Dan Tertinggal Di Universitas Negeri Yogyakarta. Jurnal Pendidikan Dan Kebudayaan, 2(1). https://doi.org/10.24832/jpnk.v2i1.538. 
Purnami, W., Ashadi, Suranto, Sarwanto, Sumintono, B., \& Wahyu, Y. (2021). Investigation of Person Ability and Item Fit Instruments of Eco Critical Thinking Skills in Basic Science Concept Materials for Elementary Pre-Service Teachers. Jurnal Pendidikan IPA, 10(1), 127-137. https://doi.org/10.15294/jpii.v10i1.25239.

Rayanto, Y. H., \& Sugianti, S. (2020). Applying Obejctivist Instructional Design of Addie Model on Learning Reading Comprehension. 477(Iccd), 795-799. https://doi.org/10.2991/assehr.k.201017.175.

Safitri, K., \& Harjono, N. (2021). Pengembangan Instrumen Penilaian Sikap Sosial Aspek Tanggung Jawab Pembelajaran Tematik Terpadu Siswa Kelas 4 SD. MIMBAR PGSD Undiksha, 4(1), 111-121. https://doi.org/http://dx.doi.org/10.23887/jp2.v4i1.33352.

Siddiq, F., Hatlevik, O. E., Olsen, R. V., Throndsen, I., \& Scherer, R. (2019). Taking a future perspective by learning from the past - A systematic review of assessment instruments that aim to measure primary and secondary school students' ICT literacy. Educational Research Review, 16. https://doi.org/10.1016/j.edurev.2016.05.002.

Siddiq, Y. I., Sudarma, I. K., \& Simamora, A. H. (2020). Pengembangan Animasi Dua Dimensi pada Pembelajaran Tematik untuk Siswa Kelas III Sekolah Dasar. Jurnal Edutech Undiksha, 8(2), 49-63. https://doi.org/10.23887/jeu.v8i2.28928.

Subagia, I. W., \& Wiratma, I. G. L. (2016). Profil Penilaian Hasil Belajar Siswa Berdasarkan Kurikulum 2013. JPI (Jurnal Pendidikan Indonesia), 5(1), 39-54. https://doi.org/10.23887/jpi-undiksha.v5i1.8293.

Sugihartini, N., \& Agustini, K. (2017). Asesmen Otentik sebagai Pendukung Desain Instruksional Jaringan Komputer Berstrategi Blended-Learning dengan Pendekatan Konstruktivistik. Journal of Education Research and Evaluation, 1(2), 82. https://doi.org/10.23887/jere.v1i2.10072.

Sugiyono. (2015). Metode Penelitian dan Pengembangan Research \& Development. Alfabeta.

Suratmi, Laihat, \& Asnimar. (2020). Development of Assessment Instruments Based on Higher Order Thinking Skills (HOTS) for Elementary School Students. Jurnal Pendidikan Sekolah Dasar (JPsd), 6(1), 199-211. https://doi.org/10.30870/jpsd.v6i2.7356.

Syauqi, K., Munadi, S., \& Triyono, M. B. (2020). Students' perceptions toward vocational education on online learning during the COVID-19 pandemic. International Journal of Evaluation and Research in Education (IJERE), 9(4), 881. https://doi.org/10.11591/ijere.v9i4.20766.

Ulfa, I. R. (2019). Implementasi Instrumen Penilaian Sikap di SDN Gunungsaren Bantul. Palapa, 7(2), 251266. https://doi.org/10.36088/palapa.v7i2.357.

Utami, D. A. P., \& Wardani, N. S. (2020). Pengembangan Instrumen Penilaian Kognitif dalam Pembelajaran Tematik Kelas 5 SD. Jurnal Ilmiah Kependidikan, 20(2), 1-18. https://doi.org/10.12345/lentera.v12i2.463.

Wahyudin, W. (2018). Optimalisasi Peran Kepala Sekolah dalam Implementasi Kurikulum 2013. Jurnal Kependidikan, 6(2), 249-265. https://doi.org/10.24090/jk.v6i2.1932.

Wartawan, P. G. (2018). Scientific Attitude of Students Learning Physics. SHS Web of Conferences, 00118. https://doi.org/http://dx.doi.org/10.23887/jere.v1i4.12498.

Wei, X., Saab, N., \& Admiraal, W. (2021). Assessment of cognitive, behavioral, and affective learning outcomes in massive open online courses: A systematic literature review. Computers \& Education, 163, 104097. https://doi.org/10.1016/j.compedu.2020.104097.

Wiana, P. J. A. E., Gading, I. K., \& Kusmariyatni, N. (2017). The Application of Authentic Assessment to Improve the Learning Outcomes of Science in the fourth-grade students of SD Negeri 2 Pupuan. Journal of Education Research and Evaluation, 1(2), 106. https://doi.org/10.23887/jere.v1i2.9841.

Wildan, W. (2017). Pelaksanaan Penilaian Autentik Aspek Pengetahuan, Sikap Dan Keterampilan Di Sekolah Atau Madrasah. Jurnal Tatsqif, 15(2), 131-153. https://doi.org/10.20414/jtq.v15i2.3.

Zulfiani, Suwarna, I. P., \& Sumantri, M. F. (2020). Science adaptive assessment tool: Kolb’s learning style profile and student's higher order thinking skill level. Jurnal Pendidikan IPA Indonesia, 9(2), 194207. https://doi.org/10.15294/jpii.v9i2.23840.

Zulkifli, M. (2018). Analisis Bentuk Evaluasi Kurikulum 2013 Mata Pelajaran Bahasa Arab di MI. AlMadrasah: Jurnal Pendidikan Madrasah Ibtidaiyah, 2(2), 125-143. https://doi.org/10.35931/am.v0i0.29. 